\title{
Badania właściwości taboru dotyczącej zgodności z systemami wykrywania pociągów
}

\begin{abstract}
$W$ artykule przedstawiono źródła powstawania zakłóceń elektromagnetycznych mogacych wpływać na poprawne działanie urzadzeń sterowania ruchem kolejowym. Zestawiono obowiqzujace $w$ Polsce dopuszczalne poziomy wystepowania zaktóceń dla wybranych typów czujników. Badania wykonywane na infrastrukturze kolejowej wymagaja odpowiedniego przygotowania zarówno merytorycznego, badanego obiektu jak i stanowiska pomiarowego. Badania wykonuje się zgodnie z przygotowanym scenariuszem uwzględniajacym możliwie wszystkie sytuacje, $w$ których badany pojazd może generować zaktócenia powodujace niestabilnq prace czujników, takie jak rozruch czy hamowanie. Przedstawiono przykładowe wyniki pomiarów wraz z kryteriami oraz sposoby przeprowadzania badań, a także szczegółowe wymagania dotyczqce aparatury pomiarowej.
\end{abstract}

\section{WSTĘP}

Potrzeba stworzenia interoperacyjnej sieci transportu kolejowego w Europie jest szczególnie ważnym a zarazem bardzo trudnym przedsięwzięciem $\mathrm{w}$ dzisiejszych czasach. Różnorodność systemów zasilania sieci trakcyjnej, systemów bezpieczeństwa oraz taboru wymusza stworzenie ujednoliconych wymagań dla wszystkich krajów wspólnoty. Jednym z elementów infrastruktury kolejowej jest system sygnalizacji obecności pociagu, zapewniający bezpieczeństwo i prawidłowe funkcjonowanie całej sieci kolejowej. W ostatnich latach bardzo dużą uwagę przywiązuje się do kompatybilności taboru $\mathrm{z}$ systemami wykrywania pociagów. Nowoczesny tabor posiada szereg rozwiązań zwiększających moc, a co za tym idzie większą liczbę urządzeń przetwarzających energię elektryczną. Wiąże się to nierozerwalnie ze wzrostem zakłóceń elektromagnetycznych generowanych przez te urządzenia. Stosowanie filtrów oraz ekranowania przewodów, a nawet całych urządzeń nie zawsze w dostatecznym stopniu eliminuje to zjawisko.

\section{RODZAJE ORAZ ŹRÓDŁA ZAKLÓCEŃ SYSTEMÓW WYKRYWANIA POCIĄGÓW}

Obwody torowe oraz liczniki osi są jednymi z najważniejszych urządzeń wykrywania pociagu. Określają one stan zajętości danego odcinka przez porównanie liczby osi na początku i końcu danej sekcji. Nieprawidłowe działanie tych urządzeń może spowodować zagrożenie w ruchu kolejowym oraz ograniczyć przepustowość linii. W obwodach torowych dużą uwagę należy zwrócić na maksymalną dozwoloną impedancję zestawu kołowego. System ten jest w stanie wykryć przejeżdżający pociąg wówczas, gdy wartość ta jest dostatecznie mała. Liczniki osi działają na zasadzie sprzężenia lub thumienia pola magnetycznego między nadajnikiem, a odbiornikiem czujnika przez oś pojazdu. System licznika osi składa się z wielu elementów, z których najważniejszymi są czujniki montowane do szyn oraz jednostka analizująca sygnały $z$ czujników. Na podstawie własnych doświadczeń i szeregu publikacji można stwierdzić, że częścią układu najbardziej narażoną na zakłócenia generowane przez tabor jest czujnik szynowy.

Istnieje wiele rodzajów oraz źródeł zakłóceń wpływających na niekorzystną pracę systemów wykrywania pociagu. Wynikają one z założeń producenta danych typów urządzeń. Można podzielić je na dwie główne części: zakłócenia elektromagnetyczne oraz czynniki fizyczne.

\section{Zakłócenia elektromagnetyczne:}

- pochodzące od taboru: falowniki, przetwornice statyczne montowane $\mathrm{w}$ wagonach pasażerskich, anteny, urządzenia elektryczne, hamulce wiroprądowe, silniki trakcyjne itp.;

- pochodzące $\mathrm{z}$ sieci trakcyjnej: prądy powrotne $\mathrm{w}$ szynie oraz w tokach szynowych.

Czynniki fizyczne:

- pochodzące od taboru: długość i prędkość taboru, geometria i materiał koła; 
- wynikające z konstrukcji urządzenia: długość obwodów torowych, czas reakcji, orientacja osi czujnika.

$\mathrm{Na}$ rysunku 1 przedstawiono schemat blokowy źródeł zakłóceń elektromagnetycznych.

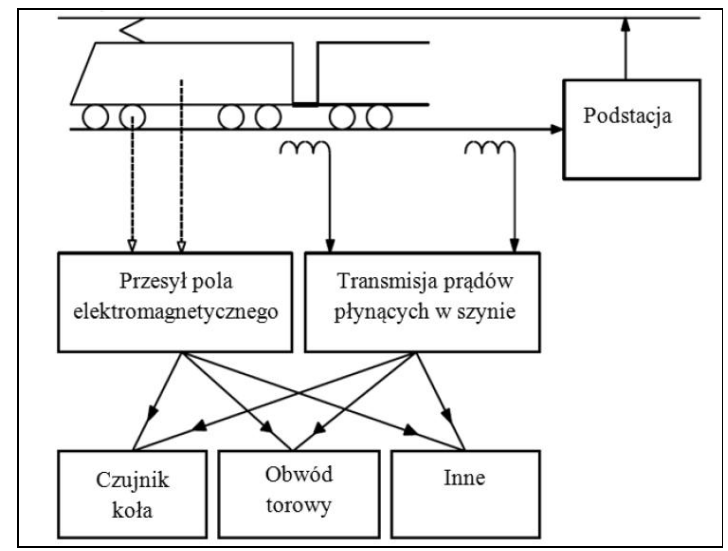

Rys. 1. Źródła zakłóceń elektromagnetycznych Źródło: opracowanie na podstawie normy PN-EN 50238

Jak wynika z przedstawionego rysunku kompatybilność elektromagnetyczną dla każdego typu urządzeń należy rozpatrywać oddzielnie. Ponadto należy zwrócić uwagę na możliwość wystąpienia zakłóceń podczas przesyłu informacji z urządzenia przytorowego do pomieszczeń nastawni.

Korzystając z metod matematycznych i symulacyjnych takich jak MES (ang. Manufacturing Execution System), RSM (ang. Response Surface Methodology), czy UKM (ang. Using Kriging Method) dowiedziono, że sposób orientacji czujnika ma decydujący wpływ na jego wrażliwość, na zakłócenia elektromagnetyczne. Dlatego podczas badań kompatybilności elektromagnetycznej montowane anteny pomiarowe powinny być zamontowane w taki sposób, aby uwzględnić najbardziej niekorzystne położenie czujnika.

\section{PRAWNE WYMAGANIA KOMPATYBILNOŚCI}

W procesie certyfikacji taboru szynowego należy spełnić wszystkie wymagania zawarte w aktualnie obowiązujących zapisach prawa w danym kraju. W Polsce organem wydającym świadectwo dopuszczenia do eksploatacji na terenie kolejowym jest Urząd Transportu Kolejowego (UTK). Organ ten na podstawie art. $25 \mathrm{~d}$ ust. 1 ustawy z dnia 23 marca 2003 r. o transporcie kolejowym (Dz.U. 2003 Nr 86 poz. 789) zobowiązany jest do ustalenia listy właściwych krajowych specyfikacji technicznych i dokumentów normalizacyjnych, których zastosowanie umożliwia spełnienie zasadniczych wymagań dotyczących interoperacyjności systemu kolei. Zgodnie z powyższym dla spełnienia wymagań kompatybilności elektromagnetycznej z częścią przytorową systemu kolejowego odnoszącą się do urządzeń wykrywania pociagu, należy spełnić wymagania normy PN-EN 50238:2003:
„Zastosowania kolejowe - Kompatybilność pomiędzy taborem, a urządzeniami wykrywania pociagów" oraz pracy Instytutu Kolejnictwa (IK) nr 4430/10 zawierającej między innymi zakresy dopuszczalnych poziomów zakłóceń urządzeń sterowania ruchem kolejowym (srk).

Wektor zakłócenia pochodzącego od natężenia prądu płynącego w szynie ma przewidywalny kierunek i zwrot. Zakłócenie pochodzące od urządzeń zamontowanych $\mathrm{w}$ pojedzie trudno jest sprecyzować, co do kierunku i zwrotu wektora natężenia pola magnetycznego. Dlatego należy określić wymagania kompatybilności dla emisji szerokopasmowej w układzie współrzędnych ortogonalnych X, Y, Z. Na poniższych rysunkach przedstawiono dopuszczalne natężenia pola magnetycznego, osobno dla każdego wektora (X, Y, Z), w odniesieniu do pasm częstotliwości pracy wybranych czujników koła opisanych w pracy IK. Przedstawione zakresy dopuszczalnych natężeń są jedynymi wymaganiami w tym zakresie obowiązującymi w aktualnych przepisach prawa polskiego. Porównując je do wymagań zawartych w CLC/TS 50238-3, są one w większości mniej restrykcyjne i nie obejmują całości pasma pomiarowego.

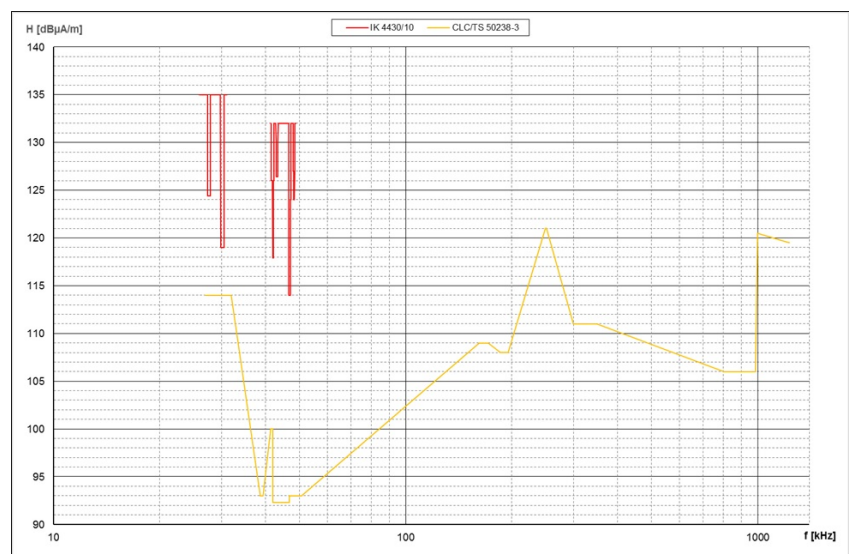

Rys. 2. Zakres dopuszczalnego natężenia pola magnetycznego dla wektora X

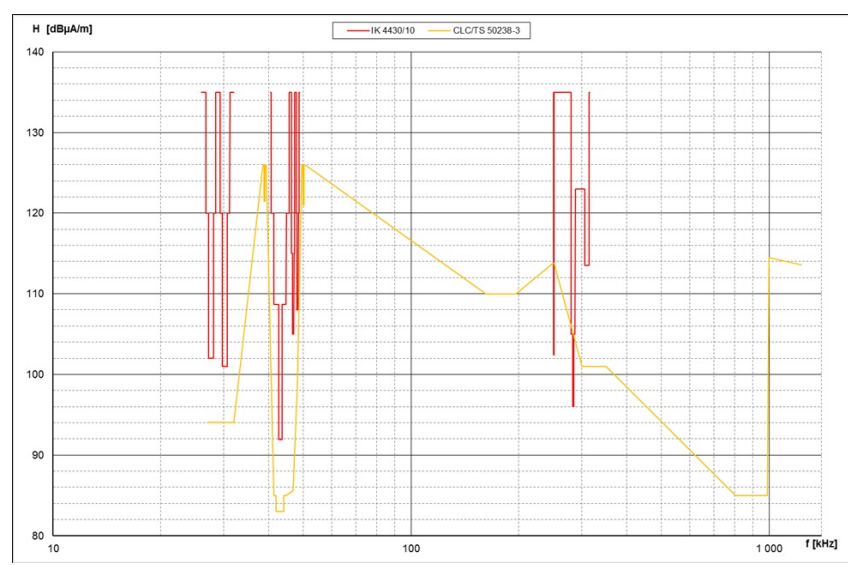

Rys. 3. Zakres dopuszczalnego natężenia pola magnetycznego dla wektora Y 


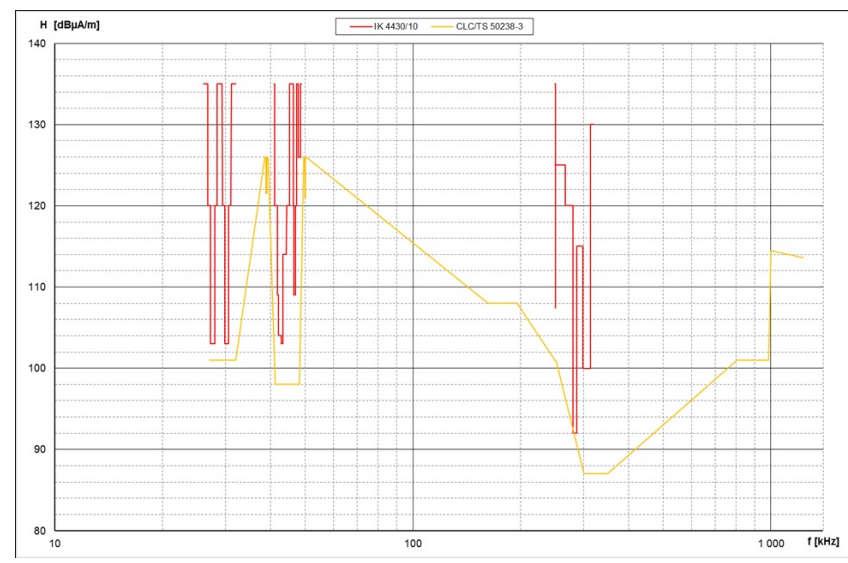

Rys. 4. Zakres dopuszczalnego natężenia pola magnetycznego dla wektora Z

Badania kompatybilności elektromagnetycznej EMC, można podzielić na dwie główne części: badania przewodzone oraz promieniowane, $\mathrm{w}$ tym badania kompatybilności pomiędzy taborem, a urządzeniami wykrywania pociagów. Proces akceptacji i wydania certyfikatu opisany jest w normie PN-EN 50238:2003.

$\mathrm{Na}$ rysunku 5 przedstawiono strony biorące udział w procesie akceptacji. Odpowiedzialność za zgodność pomiędzy taborem kolejowym, a systemami detekcji pociagu podzielona jest pomiędzy stronami odpowiedzialnymi za konkretną infrastrukturę oraz tabor. Etapy tego procesu określa czwarty rozdział przywołanej normy, w którym w sposób graficzny przedstawiono drogę do uzyskania świadectwa odbioru.

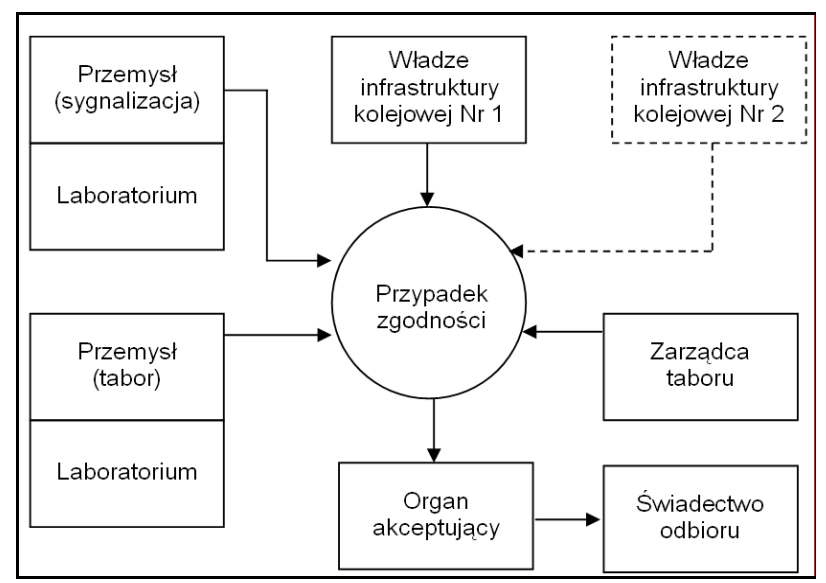

Rys. 5. Strony biorące udział w procesie akceptacji Źródlo: opracowanie na podstawie normy PN-EN 50238:2003

Parametry taboru związane z zapewnieniem zgodności z systemami detekcji pociagu opartymi na licznikach osi zawarte są również w Technicznych Specyfikacjach Interoperacyjności - Sterowanie (TSI - Sterowanie). Dokument ten odwołuje się do zapisów European Railway Agency (ERA) - ERA/ERTMS/033281 wersja 1.0. Przywołany dokument podaje wymagania kompatybilności elektromagnetycznej dla systemów zasilania w sieci AC (ang. Alternating Current). Dla systemów zasilania w sieci DC (ang. Direct Current) wymagania kompatybilności są punktem otwartym. W Polsce istnieje system zasilania trakcji $3 \mathrm{kV} \mathrm{DC} \mathrm{i}$ wszystkie wymagania będą odnoszone do tego typu systemu.

Europejski Komitet Normalizacji Elektrotechnicznej (CENELEC) jest autorem kolejnych dwóch części normy PN-EN 50238. Specyfikacja techniczna CLC/TS 50238-2 odnosi się do kompatybilności taboru z obwodami torowymi, a CLC/TS 50238-3 zawiera wymagania kompatybilności taboru z licznikami osi. Obie specyfikacje opisują sposoby oceny kompatybilności, metody pomiaru oraz wymagania, jakie powinien spełniać sprzęt pomiarowy. Nie są one umieszczone na liście prezesa UTK, dlatego mają tutaj zastosowanie informacyjne i pomocnicze. Żaden dokument powołany przez prezesa UTK nie opisuje sposobu pomiaru EMC dla urządzeń srk oraz wymagań, co do zastosowanej aparatury. Dlatego skorzystano z zapisów zawartych w specyfikacjach CLC/TS do wyboru sposobu przeprowadzania badań oraz wyboru odpowiedniej aparatury pomiarowej.

\section{BADANIA KOMPATYBILNOŚCI ELEKTROMAGNE- TYCZNEJ}

Z uwagi na szerokość zagadnienia ograniczono się do opisu sposobu przeprowadzenia badań kompatybilności elektromagnetycznej z licznikami osi. Dzięki tym badaniom możliwe jest wyeliminowanie zagrożeń już podczas badań homologacyjnych.

\subsection{Aparatura pomiarowa}

Specjalistyczny sprzęt pomiarowy stosowany do opisywanych badań składa się $\mathrm{z}$ dwóch głównych elementów: anteny pomiarowej oraz odbiornika pomiarowego.

Ze względu na szerokość pasma częstotliwości od kilkudziesięciu $\mathrm{kHz}$ do $1,3 \mathrm{MHz}$ w jakim pracyją liczniki osi, nie jest możliwe skonstruowanie jednej anteny o dostatecznie niskiej niepewności pomiaru. Stosuje się zatem dwie anteny:

- niskiej częstotliwości (LFR) - $10 \mathrm{kHz} \div 100 \mathrm{kHz}$;

- wysokiej częstotliwości (HFR) - $100 \mathrm{kHz} \div 1,3$ $\mathrm{MHz}$.

$\mathrm{Na}$ rysunku 6 przedstawiono ogólny widok anten pomiarowych zamontowanych w torowisku.

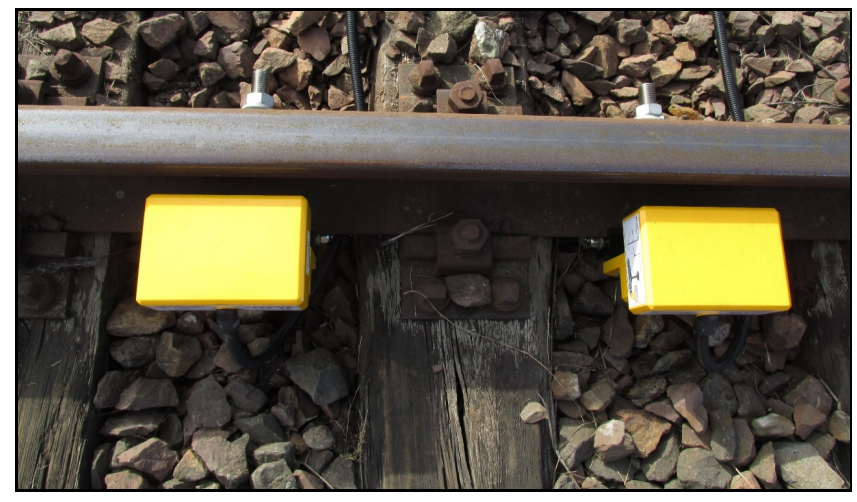

Rys. 6. Ogólny widok anten pomiarowych zamontowanych w torowisku 
Niepewność pomiaru całego łańcucha pomiarowego nie powinna być większa niż $\pm 1,75 \mathrm{~dB}$. Znaczący udział w budżecie niepewności pomiaru ma odległość anten od źródą emisji pola elektomagnetycznego, stąd szczęgólną uwagę należy zwrócić na dokładność montażu anten w torowisku. Pomiaru można dokonać zarówno aparaturą analogową jak i cyfrowa.

\subsection{Badania terenowe}

\subsubsection{Miejsce i warunki badań}

Miejsce badań powinno umożliwiać zamontowanie anten pomiarowych $\mathrm{w}$ torowisku, przy zachowaniu szczególnych warunków bezpieczeństwa. Badania należy przeprowadzić według wcześniej przygotowanego scenariusza. Pomiary należy wykonać podczas przejazdu pojazdu $\mathrm{z}$ maksymalną siłą trakcyjną oraz maksymalną siłą hamująca, dla co najmniej czterech różnych prędkości opisanych poniżej:

- prędkość v1 - bardzo mała prędkość, w przybliżeniu $5 \div 10 \mathrm{~km} / \mathrm{h}$;

- prędkość v2 - w przybliżeniu $70 \div 90 \%$ prędkości osiagniętej przy przejściu z przełączenia asynchronicznego do synchronicznego (maksymalne tempo impulsu powtórzenia);

- prędkość v3 - w przybliżeniu $70 \div 90 \%$ prędkości osiągniętej przy przejściu do hiperboli mocy (maksymalne napięcie linii DC);

- prędkość v4 - w przybliżeniu $20 \div 30 \%$ powyżej prędkości osiagniętej przy przejściu do hiperboli mocy (maksymalne napięcie linii DC).

Dla różnych jazd testowych powinna być włączona maksymalna możliwa ilość potencjalnych źródeł emisji (przetworniki trakcyjne, przetworniki pomocnicze, oświetlenie, klimatyzacja, itp.). Dla badania lokomotyw z wydzielonym zasilaniem linii ogrzewania powinno być zastosowane obciążenie rezystancyjne o minimalnej mocy $80 \mathrm{~kW}$. Badania powinny być wykonane $\mathrm{z}$ sinusoidalnym zasilaniem sieci ogrzewania. Jeśli to konieczne należy zastosować dodatkowy pojazd (lokomotywa, wagon towarowy), w celu uzyskania wymaganych parametrów (np. maksymalna siła trakcyjna maksymalna siła hamująca) badanego pojazdu. Wpływ dodatkowego pojazdu na pomierzone zakłócenie pola magnetycznego powinien być nieistotny lub co najmniej powinna być możliwość wyłączenia go z oceny.

Wagony osobowe należy badać podczas wolnego przejazdu (prędkość $5 \div 20 \mathrm{~km} / \mathrm{h}$ ) przy każdej częstotliwości zasilania linii ogrzewania. Wszystkie potencjalne źródła emisji na pokładzie badanego wagonu powinny być włączone. Wpływ lokomotywy na pomierzone zakłócenie pola magnetycznego powinien być nieistotny lub co najmniej powinna być możliwość wyłączenia go z oceny.

Należy określić liczbę jazd testowych w takich samych warunkach eksploatacyjnych w celu przedstawienia pewności, że wyniki badania są powtarzal- ne. Powinny być wykonane, co najmniej dwie jazdy testowe w takich samych warunkach.

\subsubsection{Przygotowanie obiektów do badań}

Przygotowanie obiektu do badań polega na funkcjonalnym sprawdzeniu działania i podłączenia $\mathrm{w}$ pojeździe takich elementów jak: silniki trakcyjne, silniki wentylatorów trakcyjnych, silniki napędów pomocniczych, pomocnicze przetworniki statyczne, przetwornice trakcyjne.

Ponadto zaleca się funkcjonalne sprawdzenie działania układów pomocniczych w skład, których mogą wchodzić: układ radiołączności pociagowej, układ oświetlenia zewnętrznego i wewnętrznego, układ ogrzewania i klimatyzacji.

\subsubsection{Montaż układu pomiarowego}

Przed przystapieniem do badań należy sprawdzić działanie aparatury pomiarowej w konfiguracji przewidzianej do badań. W tym celu należy wykonać przejazd testowy i porównać otrzymane wyniki przejazdu z wynikami z poprzednich pomiarów. Do odbiornika pomiarowego podłącza się anteny. W celu zminimalizowania wpływu czynników zewnętrznych antena pomiarowa powinna być umieszczona pomiędzy dwoma podkładami. Dwie anteny pomiarowe należy zamontować w odległości nie mniejszej niż $40 \mathrm{~cm}$ względem własnych środków symetrii. Nie zaleca się umieszczać anteny pomiarowej na mostku metalowym/żelaznym.

\subsubsection{Realizacja badań}

Badania kompatybilności wykonuje się przy pomocy aparatury pomiarowej i w warunkach opisanych w pkt. 4.1 i 4.2.1. Pomiary należy wykonywać dla obu stron pojazdu, umieszczając anteny kolejno przy obu szynach.

Zgodnie z wymaganiami specyfikacji CLC/TS 50238-3, dla emisji szerokopasmowej $\mathrm{z}$ cyfrowym łańcuchem pomiarowym, dla kierunku $\mathrm{X}, \mathrm{Y}$ oraz Z, należy zastosować poniższe parametry:

- zakres próbkowania:

LFR: $300 \mathrm{kHz}$ lub co najmniej trzy razy wyższa częstotliwość eksploatacyjna mierzącego licznika osi;

HFR: $3 \mathrm{MHz}$ lub co najmniej trzy razy wyższa częstotliwość eksploatacyjna mierzącego licznika osi;

- cyfrowy filtr szerokopasmowy:

LFR: rozdzielczość szerokopasmowa (RBW,

$3 \mathrm{~dB}) 10 \div 100 \mathrm{kHz}$;

HFR: rozdzielczość szerokopasmowa (RBW,

$3 \mathrm{~dB}) 10 \mathrm{kHz} \div 1,3 \mathrm{MHz}$;

obie $\mathrm{z}$ filtrem thumiącym $40 \mathrm{~dB} /$ dekadę.

W przypadku zarejestrowania przekroczenia wartości dopuszczalnych, pomiary dla tych pasm częstotliwości należy powtórzyć minimum trzykrotnie.

Poniższe rysunki przedstawiają przykładowe zarejestrowane wartości natężenia pola magnetycznego emitowanego przez pojazd podczas rozruchu i hamowania wraz z zaznaczonym limitem zgodności. 


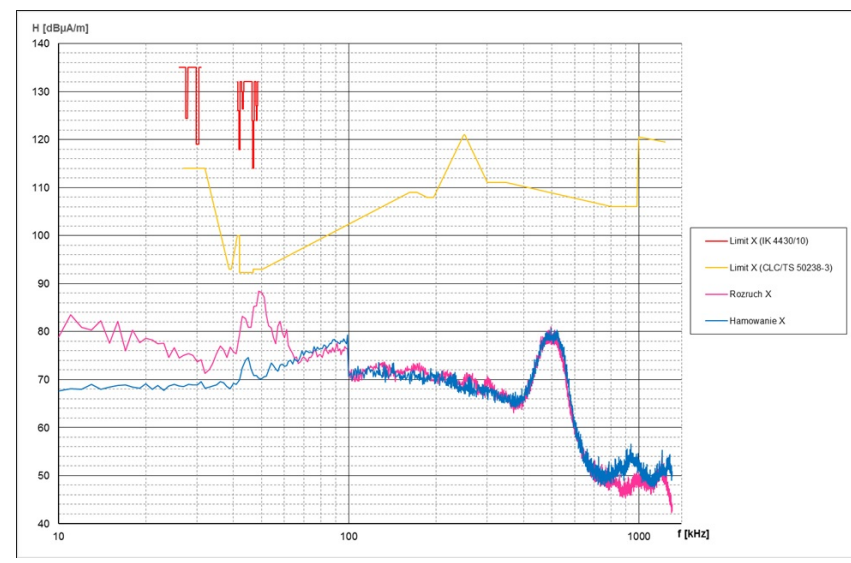

Rys. 7. Zarejestrowane wartości natężenia pola magnetycznego dla osi $\mathrm{X}$

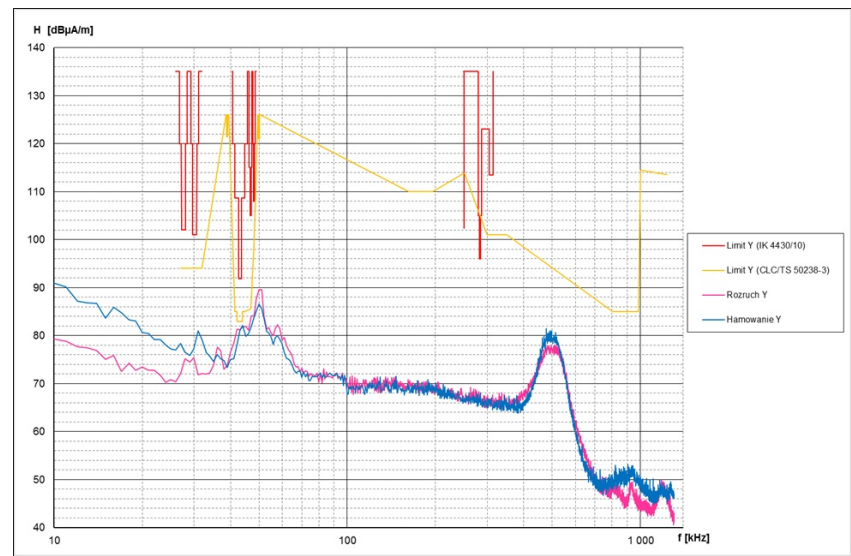

Rys. 8. Zarejestrowane wartości natężenia pola magnetycznego dla osi Y

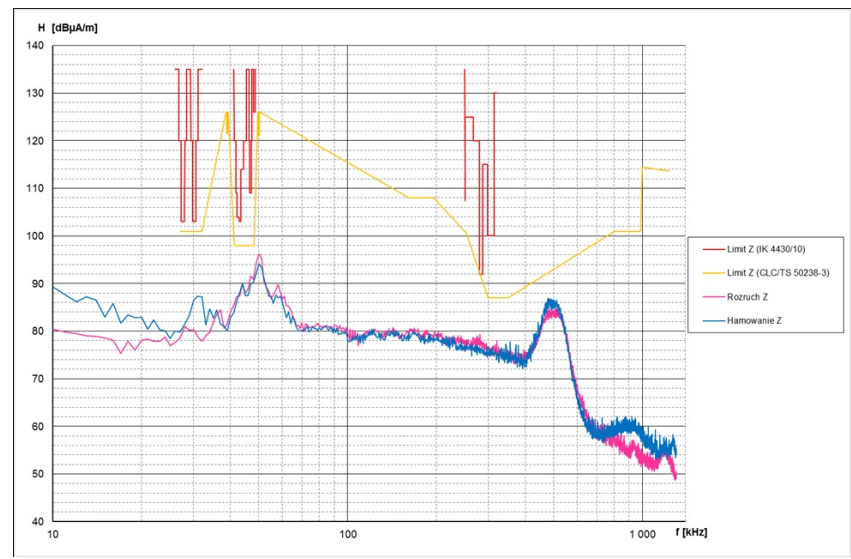

Rys. 9. Zarejestrowane wartości natężenia pola magnetycznego dla osi Z

\subsubsection{Zakończenie badań}

Zakończenie pomiarów następuje po dokonaniu oględzin końcowych obiektu badań i aparatury pomiarowej. W przypadku wątpliwości, co do uzyskanych wyników lub zauważonych nieprawidłowości, pomiary należy powtórzyć. Następnie demontuje się układ pomiarowy.

\subsection{Kryteria oceny wyników}

$\mathrm{Na}$ podstawie zapisów pkt. 2 dokumentu ILACG8:03/2009: „Wytyczne dotyczące przedstawiania zgodności ze specyfikacją", stosuje się następujące kryteria oceny:
- zgodność - jeśli wynik pomiaru powiększony o niepewność nie przekracza wartości dopuszczalnych;

- niezgodność - jeśli wynik pomiaru zmniejszony o niepewność przekracza wartości dopuszczalne;

- nie można stwierdzić zgodności - jeśli wynik pomiaru zwiększony lub zmniejszony $\mathrm{o}$ niepewność zachodzi na granicę dopuszczalną.

\section{Podsumowanie}

Potrzeba interoperacyjności transportu kolejowego w Europie jest istotnym problemem w dzisiejszych czasach, a zachowanie kompatybilności taboru $\mathrm{z}$ infrastrukturą wymaga zaangażowania $\mathrm{i}$ współpracy, zarówno producentów taboru, jak i urządzeń wykrywania pociagu. Niezbędne jest, zatem stosowanie ujednoliconych wymogów w całej Europie zapewniających bezpieczeństwo i prawidłową pracę całego systemu kolei. Wykonywanie pomiarów kompatybilności taboru z systemami detekcji pociagu już podczas badań homologacyjnych zapewnia bezpieczeństwo oraz poprawne funkcjonowanie sieci kolejowej eliminując przypadki nieprawidłowego działania urządzeń sterowania ruchem kolejowym.

\section{LITERATURA}

[1] 2012/88/UE: 2012: Decyzja komisji z dnia 25 stycznia 2012r. w sprawie technicznej specyfikacji interoperacyjności w zakresie podsystemów „Sterowanie” transeuropejskiego systemu kolei.

[2] Adamski D., Białon A., Furman J., Kazimierczak A.: Problematyka odporności na zaktócenia czujników kota wykorzystywanych $w$ urzadzeniach srk, LogistykaNauka/6/2011, str. 6-13, Instytut Kolejnictwa, 2011 Warszawa.

[3] Adamski D., Biatoń A., Furman J., Ortel K., Zawadka Ł.: Konsekwencje wptywu pól magnetycznych na liczniki osi, Logistyka-Nauka/3/2014, str. 29-33, Instytut Kolejnictwa, 2014 Warszawa.

[4] Biatoń A., Adamski D., Pajka P.: Badanie kompatybilności elektromagnetycznej taboru z urzqdzeniami wykrywania pociagu z uwzględnieniem normy EN 50238, Problemy Kolejnictwa, z. 152, str. 51-66, Instytut Kolejnictwa, 2011 Warszawa.

[5] Biatoń A., Dlużniewski A., John L.: Emisja zaburzeń radioelektrycznych generowanych przez tabor kolejowy, Problemy Kolejnictwa, z. 152, str. 51-66, Instytut Kolejnictwa, 2011 Warszawa.

[6] Białoń A., Furman J., Kazimierczak A., Zawadka L.: Dopuszczalne parametry zakłóceń dla obwodów torowych stosowanych na PKP, Logistyka-Nauka/6/2011, str. 177-186, Instytut Kolejnictwa, 2011 Warszawa.

[7] Białoń A., Kazimierczak A., Furman J., Zawadka L., Adamski D., Pajka P., Ortel K.: Określenie dopuszczalnych poziomów i parametrów zakłóceń dla urzqdzeń sterowania ruchem kolejowym, Praca nr 4430/10. Instytut Kolejnictwa, 2011Warszawa.

[8] CLC/TS 50238-2: 2010: Kolejnictwo - Kompatybilność pomiędzy taborem a urzadzeniami wykrywania pociagu-Czesść 2: Kompatybilność z obwodami torowymi. 
[9] CLC/TS 50238-3: 2010: Kolejnictwo - Kompatybilność pomiędzy taborem a urzqdzeniami wykrywania pociagu - Część 3: Kompatybilność z licznikami osi.

[10] Czuchra W., Jakubas W., Zajac W.: Zaktócenia w obwodach torowych od pól magnetycznych pojazdów trakcyjnych, Czasopismo techniczne, Elektrotechnika, z. 13, str. 31-39, Politechnika Krakowska, 2011 Kraków.

[11] ERA/ERTMS/033281: 2011: Interfaces between control-command and signaling trackside and other subsystems.

[12] ILAC-G8: 03/2009: Wytyczne dotyczqce przedstawienia zgodności ze specyfikacja, Komitet ILAC ds. Akredytacji, Silverwater Australia.

[13] Persichini R., Febo D., Calá V., Malta C., Orlandi A.: EMC Analysis of Axle Counters in the Italian Railway Network, Vol.57. NO. 1. pages 44-51,Eurail Electromagnetic Compatibility, IEEE Transactions, FEB. 2015.
[14] PN-EN 50238: 2003: Zastosowania kolejowe Kompatybilność pomiędzy taborem a urzqdzeniami wykrywania pociagów.

[15] Zamani A., Mirabadi A.: Analysis of sensor orientation in Railway axle counters using Response Surface Methodology, SASTech, 01/2011, str. 1-7, Khavaran Higher-education Institute, 2011 Mashhad, Iran.

[16] Zamani A., Mirabadi A.: Optimization of sensor Orientation in Railway Wheel Detector, Using Kriging Method, Journal of Electromagnetic Analysis and Applications, 2011,3, str. 529-536, 2011.

[17] Zhang S., Lee W. K., Pong P.W.T.: Train Detection by Magnetic Field Measurement with Giant Magnetoresistive Sensors for High-Speed Railway, Applied Mechanics and Materials, Vols. 284-287 (2013), pages 2102-2114, Trans Tech Publications, 2013 Switzerland. 